\title{
Development of Achievement Motivation Training for Teachers in Madrasah Aliyah Negeri, Mataram City
}

\author{
Muazar Habibi \\ Lecturer and Psychologist, S1 Early Childhood Education FKIP, Mataram University, muazar.habibi@unram.ac.id
}

\begin{abstract}
The focus of this research is the development of the achievement motivation training model (PMB model) with the capacity of increasing the achievement motivation of teachers. Inductive and qualitative data were collected and analyzed, the results further emphasize the significance of generalization.

The experts test for the development of model indicated that the accuracy and usability aspects as very precise and useful, while the feasibility aspect was very feasible. Also, the users test revealed the accuracy to be very precise, the usability very useful, while the feasibility aspects was considered very feasible. Series of effectiveness tests were conducted with regards to the achievement motivation on six aspects: have high levels of responsibility, dare to take and assume risks, have realistic goals, have a thorough work plan and strive to realize the goals, utilizing feedback concrete in all activities performed and look for opportunities to realize the programmed plans. The results show that this training improves all aspects of achievement motivation with very high category. Also, the developed PMB model has a high effectiveness because $80 \%$ of participants increase in achievement motivation. However, its implementation can be extended to all public and private in efforts to improve the teachers' achievement motivation.
\end{abstract}

\section{Keywords: Model Training and Achievement Motivation}

\section{INTRODUCTION}

Teacher achievement motivation is defined as any element that inspires, directs and encourages a teacher to take action and overcome all challenges and obstacles in order to achieve educational goals. It makes a teacher to be passionate in carrying out his duties in any situation. The motivation achievements in this regard include; high level of responsibility, taking risks, having realistic goals and striving to achieve same, having a comprehensive work plan, etc.

The achievement motivation training method currently in use is still relevant and genuine as it captures activities with numerous achievement motivation for employees or workers but not specifically for teachers. Therefore, there is a need to develop an Achievement Motivation Training Model (PMB) that can be used to find out and improve teacher achievement motivation.

Therefore, the purpose of this research is to develop a PMB model with the capacity of improving teacher achievement motivation.

\section{LITERATURE REVIEW}

According to Hamalik (2010: 68), a training involves a series of efforts carried out in providing assistance to individuals through the help of the professionals. The whole action is aimed at improving the work ability, effectiveness and productivity of the participants in a certain occupation or organization.

Sikula (2010: 67) reported the three objectives of training as 1) developing expertise, therefore work can be completed quickly and more effectively, 2) developing knowledge, therefore work can be resolved rationally, and 3) developing attitudes, such that there can be cooperation between the employees and the management. Also, Buckley (2011: 143) revealed that the purpose of training is for an individual in a work situations to be able to do certain tasks or jobs satisfactorily.

There are steps commonly used in developing training programs as outlined by William (2010: 290). These principally include, a) analysis or assessment of needs, b) creation of training and development objectives, c) program content, d) principles learning, e) program implementation, f) expertise, knowledge and ability of workers, and g) evaluation. And according to Sikula (2010: 67), training methodology is a strategy used to achieve the objectives of the training curriculum. And that the three most important things to be considered in training methodology are the training planning, training methods and training media.

There is no specific definition of effectiveness but according to Gibson (2010: 83), effectiveness is seen from three perspectives, a) from an individual perspective, b) from a group perspective, and c) from an organizational perspective. Also, PMB has three motives that need to be known as the basis of a individual's behavior, these are: 
achievement motives, affiliation motives and ruling motives. And as suggested by McClelland (Mangkunegara, 2011: 68), there are six characteristics of people who have high achievement motivation. These are: (1) Have a high level of personal responsibility, (2) Dare to take and assume risk, (3) Have realistic goals, (4) Have a comprehensive work plan and determine to realize the goals, (5) Utilize concrete feedback in all activities carried out, and (6) Seek for opportunities to realize a programmed plan

\section{RESEARCH METHODOLOGY}

This study was conducted at the Madrasah Aliyah Negeri in Mataram city. It is a development research which is a type of descriptive qualitative study. The data were collected by the triangulation or combined technique. And upon analysis of the data, the results emphasize the meaning of generalization.

The steps taken in this development research are shown in Figure 1, consisting of Stage 1 to 7, starting with data collection, model formation and then its implementation through pre-testing and post-testing.

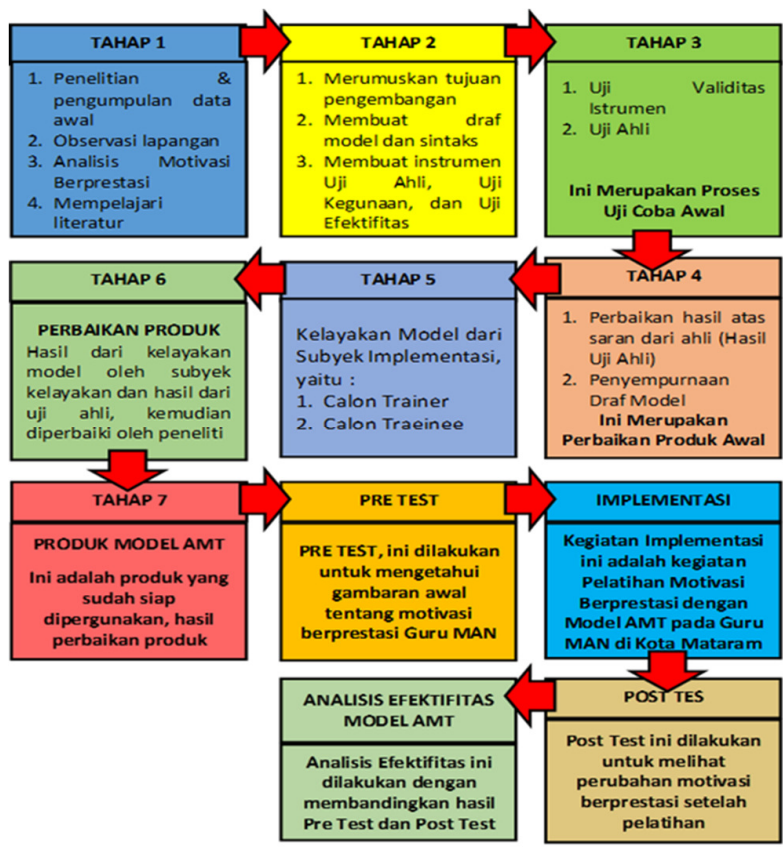

Figure 1. Adopting Development Research Flow. Theory of Research and Development Borg and Gall.

The instrument validity test in this study includes the PMB Model instrument, the PMB Model feasibility instrument and the PMB Model effectiveness instrument. According to Gregory (2000: 203), content validation can be used in testing the validity of the instrument or questionnaire because it is more quantitative. Each instrument is assessed quantitatively by two experts using a four-point scale: 1 - irrelevant, 2 - somewhat relevant, 3 quite relevant, and 4 - very relevant.
Table 1. Range of Assessment

\begin{tabular}{|l|l|}
\hline Score ranges & Assessment \\
\hline $61.76-76.00$ & Very accurate \\
\hline $47.50-61.75$ & Accurate \\
\hline $33.25-47.49$ & Less accurate \\
\hline $19.00-33.24$ & Inaccurate \\
\hline
\end{tabular}

The validation results of the PMB model instrument are as follows 1) the usability has a validation value of 0.9 which is classified as very high, 2) the feasibility has a content validation value of 1.0 which is classified as very high, and 3) the accuracy has a content validation value of 1.0 which is also classified as very high. Generally, the results of validation for users are: 1) on the usability aspects, the validation value of 1.00 is classified as very high, 2) on the feasibility aspects, the content validation value of 1.0 is classified as very high, and 3) on the aspects of accuracy, the content validation value of 1.0 is classified very high.

Then the professionals used the pre-test and posttest as the instruments for knowing the effectiveness of the PMB models. The results of these are as follows 1) the pretest instrument gave a content validation value of 0.82 which is classified as high, and 2) the results of the post-test instrument obtained a content validation value of 0.82 , this is also classified as high.

The data source is classified into 1) primary data, which is obtained directly from expert tests, user feasibility tests and effectiveness tests. The Expert Test consists of three experts which are the Teachers, Psychologists and Educational Technology Experts. The User Feasibility Test is conducted by three users, with teaching background, from Widyaiswara. The Effectiveness Test is carried out by the pre-test and post-test. The expert and user feasibility tests include both the quantitative and qualitative data. The quantitative data is obtained in an assessment based on the Likert scale description with a range values of 1 to 4 , as well as in some related aspects of usability, feasibility and accuracy, while the qualitative data is obtained based on the results of discussions, suggestions, comments or criticisms written by experts and users on the provided instrument. The effectiveness test data only involve the quantitative data used to see an overview of the increase in achievement motivation and effectiveness of the PMB model, 2) secondary data, which is obtained from scientific journals, theoretical books, reports, archives, various government regulations, results of relevant research, etc.

The data analysis techniques employed include data reduction, data presentation and data verification. 
Table 2. Criteria for Usability Assessment of PMB Model

\begin{tabular}{|l|l|}
\hline Score ranges & Category \\
\hline $32.5-40.0$ & Very useful \\
\hline $25.0-32.4$ & Useful \\
\hline $17.5-24.9$ & Less useful \\
\hline $10.0-17.4$ & Useless \\
\hline
\end{tabular}

1) Accuracy aspects of the PMB model

The calculation of the accuracy aspect is shown as, the maximum score is $19 \times 4=76$, and the minimum score is $19 \times 1=19$, the difference is $76-19=57$, the score interval between categories is $57 / 4=14.25$, then assessment criteria can be arranged as follows:

Table 3. Criteria for Accuracy Aspects of PMB Model

\begin{tabular}{|l|l|}
\hline Score ranges & Category \\
\hline $32.5-40.0$ & Very useful \\
\hline $25.0-32.4$ & Useful \\
\hline $17.5-24.9$ & Less useful \\
\hline $10.0-17.4$ & Useless \\
\hline
\end{tabular}

2) Feasibility aspect of the PMB model

This is the calculation results of the feasibility aspects. he maximum score is $7 \mathrm{x} 4=28$, and the minimum score is $7 \times 1=7$, the difference of maximum and minimum score is $28-7=21$, the score interval between categories $21 / 4=5.25$, then, the assessment criteria can be arranged as follows:

Table 4. Criteria for Feasibility Aspects of PMB Model

\begin{tabular}{|c|c|}
\hline Score ranges & assessment \\
\hline $22.75-28.00$ & Very feasible \\
\hline $17.50-22.74$ & Feasible \\
\hline $12.25-17.49$ & Less feasible \\
\hline $7.00-12.24$ & Not feasible \\
\hline
\end{tabular}

The analysis of the effectiveness of this achievement motivation training model is guided by PP No. 19 of 2005 concerning National Education Standards and Minister of Education and Culture No.66 of 2013 concerning Educational Assessment Standards outlined in the assessment guidelines by the National Education Standards Agency (BSNP 2006: 78).

The formula is described as follows: $\frac{\text { actual score (s) }}{\text { ideal score (is) }} X 100 \%=\%$ score

According to Sugiyono (2006;13), the above formula is used to know the percentage score for each subject.
The explanation to this is given as follows

a. The actual score is the answer given by all respondents to the submitted questionnaires.

b. The ideal score is the highest score or weight or the highest score all respondents are assumed to have chosen.

The effectiveness test of the model was carried out through pre-test and post-test activities, these were carried out before and after the PMB implementation.

This test aims to check the ability of the PMB model to increase the teacher achievement motivation.

To obtain the results of the pre-test and post-test data processing, the assessment rules used was in accordance to what was given by Sugiyono (2006: 183). According to this rule, "to determine the high, medium and low categories, firstly, the minimum index value, maximum and interval and the interval distance must be determined" as follows:

1. Formula for original deviation score

$$
\mathrm{X} 2-\mathrm{X} 1=\mathrm{D}
$$

Explanation:

$\begin{array}{lll}- & \mathrm{X} 1 & =\text { Pre-test score } \\ - & \mathrm{X} 2 & =\text { Post-test score } \\ - & \mathrm{D} & =\text { Deviation value }\end{array}$

2. Percentage index calculations are calculated using the following formula:

$\mathrm{X} 1 \%=\frac{\mathrm{X} 1}{\text { maximal score }} X 100 \%$ and
$\mathrm{X} 2 \%=\frac{X 2}{\text { maximal score }} X 100 \%$

Explanation:

- $\mathrm{X} 1$ and $\mathrm{X} 2=\mathrm{X} 1$ (pre-test value), $\mathrm{X} 2$ (post-test value)

- Maximal score $=156$

- $\mathrm{X} 1 \%$ and $\mathrm{X} 2 \%=$ deviation value of pre-test and posttest percentages

3. Formula for percentage deviation value

$$
\mathrm{X} 2 \%-\mathrm{X} 1 \%=\mathrm{D} \%
$$

Explanation:

- $\mathrm{X} 1 \%=$ pre-test score percentage

- $\mathrm{X} 2 \% \quad$ = post-test score percentage

- $\mathrm{D} \%=$ percentage deviation value (final value)

4. Formula to find out assessment category

$$
\begin{aligned}
\text { Category Interval } & =\frac{D \% \text { highest }-D \% \text { lowest }}{\text { number of category }} \\
8.25 & =\frac{60-27}{4}
\end{aligned}
$$

5. Formula for final result calculation (final percentage) of group

$$
P \text { Total }=\frac{\sum \mathrm{p}}{\mathrm{N}}
$$


Explanation:

$$
\begin{array}{ll}
\text { - } \sum \mathrm{p} & =\text { number of percentage } \mathrm{D} \% \\
\text { - } \mathrm{N} & \text { = number of subject } \\
\text { - } \mathrm{P} \text { Total } & =\text { average of total percentage }
\end{array}
$$

Thus, the categorization of respondents' answers for each research item is as follows:

Table 5. The categorization of respondents' answers (Sugiyono, 2006;183)

\begin{tabular}{|c|c|}
\hline \multicolumn{2}{|c|}{ Before conversion } \\
\hline Presentase & $\begin{array}{c}\text { Kategori Motivasi } \\
\text { Berprestasi }\end{array}$ \\
\hline $75 \leq \eta \leq 100$ & Sangat Tinggi \\
$50 \leq \eta<75$ & Tinggi \\
$25 \leq \eta<50$ & Cukup Tinggi \\
$\eta<25$ & Rendah \\
\hline
\end{tabular}

\begin{tabular}{|c|c|}
\hline \multicolumn{2}{|c|}{ After conversion } \\
\begin{tabular}{|c|c|}
\hline $\begin{array}{c}\text { Interval Tingkat } \\
\text { Keberhasilan }\end{array}$ & Kriteria \\
\hline $51,75 \%-60.00 \%$ & Tinggi Sekali \\
\hline $43,50 \%-51,74 \%$ & Tinggi \\
\hline $35,25 \%-43,49 \%$ & Sedang \\
\hline $27.00 \%-35,24 \%$ & Kurang \\
\hline
\end{tabular}
\end{tabular}

The quantitative data is analyzed by scoring and it involves the following steps:

\section{3) Usability aspects of the PMB model}

Considering the arguments presented by several experts in the Joint Committee on Standards for Educational Evaluation (Joint Committee, 2011), the criteria are calculated using the minimum and maximum score. Get the difference between these two values and then divide by the number of categories. The results are the score interval ranges for each assessment categories.

The maximum score here is $10 \times 4=40$, and the minimum score is $10 \times 1=10$, the result of the difference between these scores is $40-10=30$, the score interval between categories is $30 / 4=7.5$, then the assessment criteria can be arranged as follows:

The success criteria for increasing achievement motivation are as stated below.

1. If there is an increase in the score of achievement motivation in the results of the pre-test compared with that of the post-test.

2. If there is $75 \%$ of the number of trainees whose scores increase with high categories $(43.50 \%-51.74 \%)$ to very high $(51.75 \%-60.00 \%)$, as in the table above.
(Benchmark Reference Assessment/BRA, Director of Education Personnel, 2008: 18)

\section{RESEARCH RESULTS AND DISCUSSION}

1. Sub-focus 1 - Development of achievement motivation training models for teachers that produce achievement motivation. According to the expert for the development of the PMB model, the accuracy and usability aspects are classified as very accurate and very useful. Likewise, the feasibility aspect is classified as very feasible and feasible. Also, the user test results are classified as very accurate and accurate for accuracy, very useful and useful in the aspect of usability and then feasible for the feasibility aspects.

Then the next step is to improve based on the advice provided by experts and users. The stages of improvement are:

a) Improvement on the advice based on quantitative values on the assessment instrument

There are no stages of improvement based on these because the results of evaluations from experts and users on usability, accuracy and feasibility are very useful, very accurate and very feasible.

b) Improvement on the advice based on qualitative values are suggestions and notes provided by experts and users.

1) Based on the expert's advice

Experts I and II did not provide suggestions for improvement but Expert III did: (a) material in PowerPoint should be more interesting and have a better format, (b) material for implementing activities should always come with introduction, main activities and closing, (c) assignments might be attached as Material 3, (d) at the end of work there should be materials for conclusions, reflections and questions as tasks, (e) there should be material for final evaluation which could be tests, interviews or questions and work products, (f) literature needs to be added to its revisions, and (g) media should be more varied. And all the improvements have been completed according to the expert advice.

2) Based on user's advice

All the three users did not provide suggestions and input for improvement. The only advice given was in aspect of appreciation, hope and utilization of the developed PMB model, which bothers on the fact that the PMB model was very useful for teachers in increasing their achievement motivation, could be used as a guide or reference in training achievement motivation and that the model is very feasible when it comes to developing the teachers.

1. Sub-focus 2 - Development of achievement motivation training models for teachers in improving achievement motivation

The analysis of the activity process was reviewed from each aspect of achievement motivation and effectiveness of the PMB model. This sub-focus description includes: (a) analysis of the activity process in each aspect of achievement motivation, and (b) the effectiveness test analysis of the PMB model. 
a. Assessment of each Aspect

Table 6. The Percentage of Improvement on each Aspect

\begin{tabular}{|c|l|c|c|c|}
\hline \multicolumn{2}{|c|}{ Aspect } & Pretest & Posttest & $\begin{array}{c}\text { Impro- } \\
\text { vement }\end{array}$ \\
\hline $1^{\text {st }}$ aspect & $\begin{array}{l}\text { Have a high } \\
\text { level of } \\
\text { personal } \\
\text { responsibility }\end{array}$ & $40 \%$ & $96 \%$ & $56 \%$ \\
\hline $2^{\text {nd }}$ aspect & $\begin{array}{l}\text { Dare to take } \\
\text { and carry on } \\
\text { the risk }\end{array}$ & $44 \%$ & $96 \%$ & $53 \%$ \\
\hline $3^{\text {th }}$ aspect & $\begin{array}{l}\text { Have realistic } \\
\text { goals }\end{array}$ & $43 \%$ & $95 \%$ & $51 \%$ \\
\hline $5^{\text {th }}$ aspect & $\begin{array}{l}\text { Have a } \\
\text { comprehensive } \\
\text { work plan and } \\
\text { strive to } \\
\text { realize goals. }\end{array}$ & $\begin{array}{l}\text { Utilize of } \\
\text { concrete } \\
\text { feedback in all } \\
\text { activities } \\
\text { carried out. }\end{array}$ & $\begin{array}{l}40 \% \\
6^{\text {th }} \text { aspect }\end{array}$ & $\begin{array}{l}\text { Look for } \\
\text { opportunities } \\
\text { to realize a } \\
\text { programmed } \\
\text { plan. }\end{array}$ \\
\hline
\end{tabular}

Considering the table above, it is clear that every aspect of achievement motivation in the groups increases in the very high category according to the categorization in Table 5. This can be seen clearly in Figure 2.

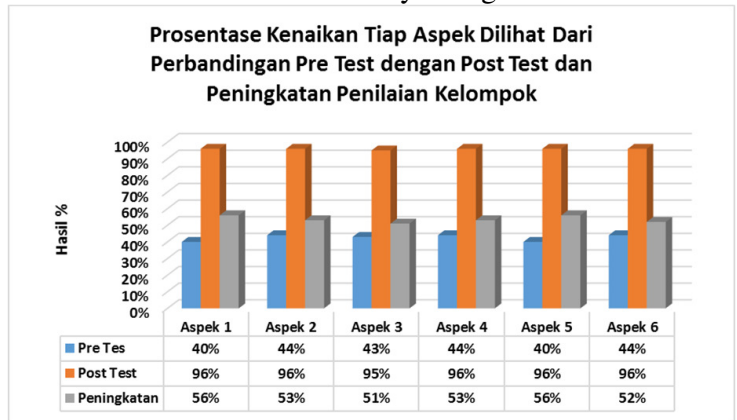

Figure 2. Graph of Increase in Percentage of Each Aspect Seen From the Comparison of Pretest and Posttest and Increased Group Assessment

b. The Model Effectiveness Test

The model effectiveness test was carried out through pretest and post-test activities and it aims to reveal whether the PMB model is able to increase teacher achievement motivation effectively or not.

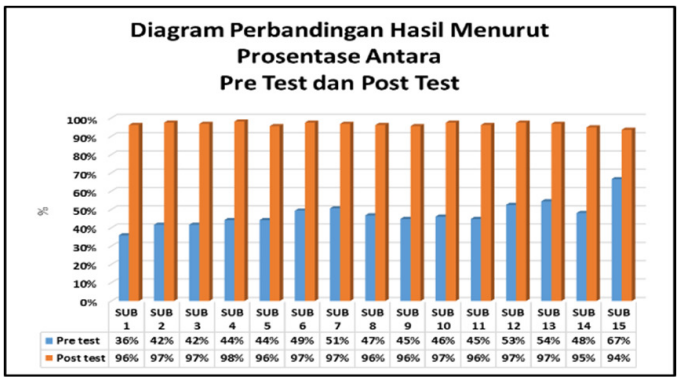

Figure 3. The Result Comparison Chart based on Pre-test and Post-test

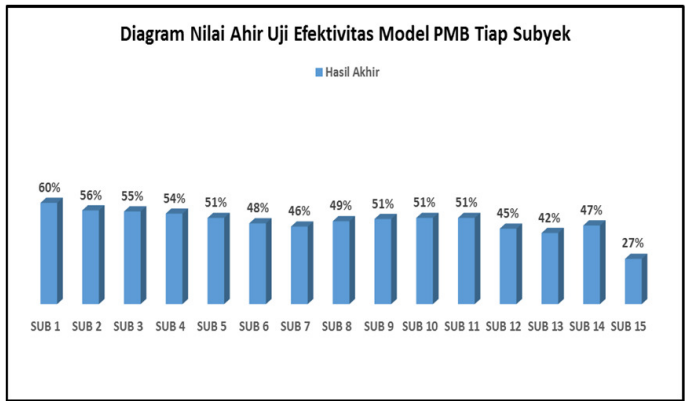

Figure 4. The Final Value Chart of the Effectiveness of PMB Models for Each Subject

The charts in figures 4 and 5 showed that there is an increase between the pre-test and post-test. Considering the 15 subjects, 3 are with very high result categories, 9 subjects with high results categories, 2 subjects with medium category and 1 subject with low category. The table and chat in Figure 6 describe the results of the training in a group

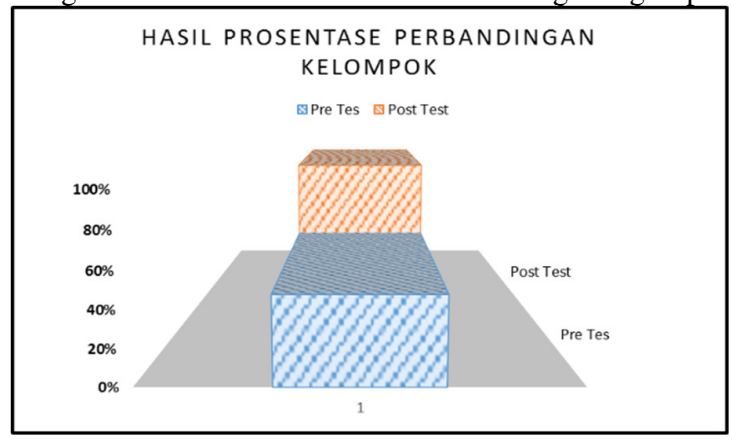

Figure 5. Results Comparison Percentage Chart by Group

The graph in Figure 6 shows the percentage difference between pre-test and post-test, which is obtained from the reduction of the percentage of the post-test and pretest results. Figure 7 shows the results according to categories, which are, very high, high, medium and low. 


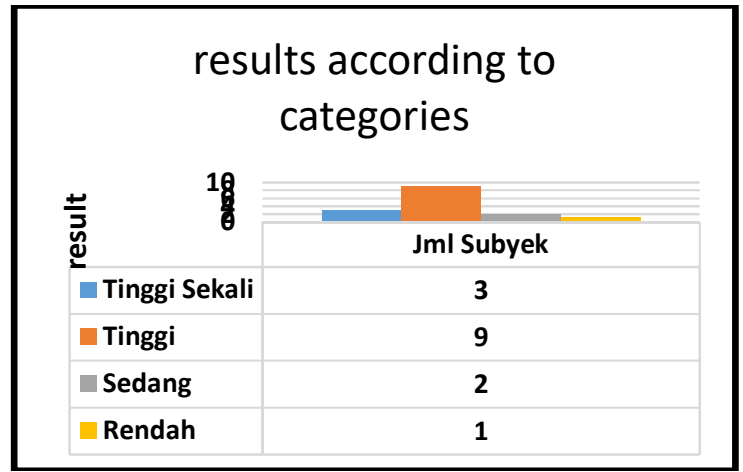

Figure 6. Results Chart by Category

The chart in Figure 8 helps in the interpretation of the final results.

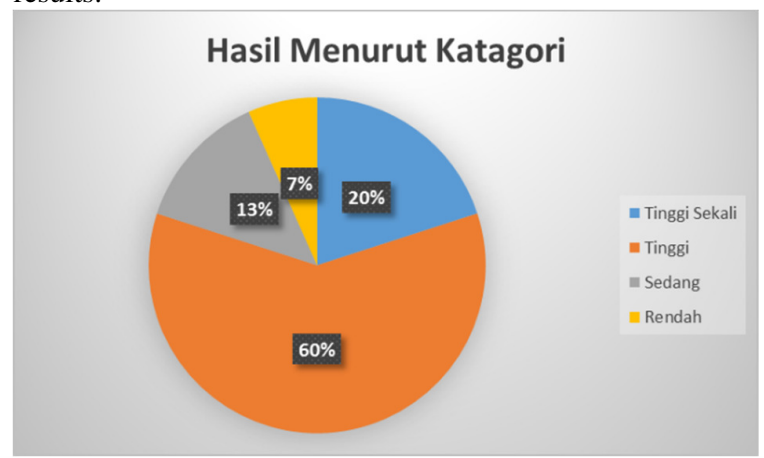

Figure 7. Percentage Chart of PMB Model Effectiveness Test Results

Considering the Figure 8, there are $7 \%$ of subjects or 1 subject whose achievement motivation is improved but below the standard set by a low category, $13 \%$ of subjects or 2 people with average category, $20 \%$ of subjects or 3 people with a high category and $60 \%$ of subjects or 9 people with a very high category. Specifically, the developed PMB model has a high effectiveness value because $80 \%$ of participants experience an increase in achievement motivation according to established standards given by the chart in Figure 9.

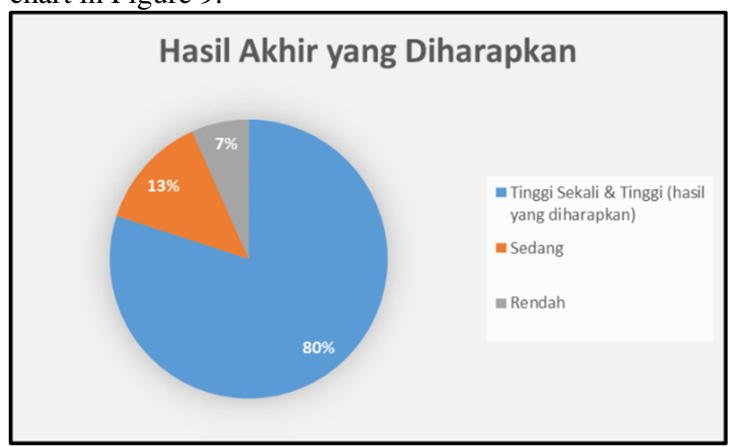

Figure 8. Percentage Chart of Expected Final Results \& Effectiveness Test of PMB Model

\section{CONCLUSIONS AND SUGGESTIONS \\ A. Conclusion}

This research has been able to produce an achievement motivation training model (PMB Model) for teachers with test series of expert and users to find out its validity and effectiveness. The model is used to train and increase in teacher achievement motivation. And according to the training results, the PMB Model was effectively able to improve every aspect of achievement motivation.

B. Suggestion

The PMB Model socialization needs to be carried out with the aim of increasing the achievement motivation of public and private school teachers. And efforts are being channeled at improving the model to suit the conditions of each region.

\section{REFERENCES}

[1] Buckley, Michael J. \& Caple, Betty. 2010. Organisasi: Perilaku, Struktur, Dan Proses: Edisi Kelima. Jakarta: Erlangga.

[2] Borg, W. D. \& Gall, MD. 1983. Educational Research: An Introduction. New York : Longman.

[3] Gibson, I. D. 2010. Organisasi, Perilaku, Struktur, Proses ( Alih Bahasa Nunuk Adiarni). Jakarta : Penerbit Binarupa Aksara.

[4] Gregory, Robert J. 2000. Psychological Testing: History, Principles, and Applications. Boston: Allyn and Bacon.

[5] Hamalik, Oemar. 2010. Kurikulum dan Pembelajaran. Jakarta: Bumi Aksara.

[6] Joint Commitee on Standards for Educational Evaluation. Standards for evaluations of educational programs, projects, and materials. New York: McGraw-Hill.

[7] Joyce, Bruce and Marshal Weil. 1992. Models of Teaching. Boston: Allyn and Bacon.

[8] Mangkunegara, A. P. 2011. Evaluasi kinerja SDM. Bandung: PT Refika Aditama.

[9] Mangkunegara, A.A. Anwar Prabu. 2011. Manajemen Sumber Daya Manusia Perusahaan. Cetakan Kedua. Bandung : Remaja Rosdakarya.

[10] Peraturan Pemerintah, 2005. PP Nomor 19 tahun 2005 "Standar Pendidikan Nasional". Lembaran Negara. 
[11] Permendikbud, 2013. Permendikbud Nomor 66 tahun 2013 "Standar Penilaian Pendidikan. Lembaran Negara.

[12] Sugiyono, 2014. Memahami Penelitian Kualitatif, Bandung Alfabeta.

[13] Sugiyono. 2012. Metode Penelitian Kuantitatif, Kualitatif, dan R\&D. Bandung: Alfabeta.

[14] Sikula. A.E. 2010. Manajemen Sumber Daya Manusia. Bandung : Erlangga.

[15] William, Castetter B. 2010. The Personnell Function in Educational Administration: Macmillan. 